\title{
Hexavalent chromium reduction by metal resistant and halotolerant Planococcus maritimus VITP21
}

\author{
Sangeetha Subramanian, Silviya Sam and Gurunathan Jayaraman* \\ School of Biosciences and Technology, VIT University, Vellore, 632014, Tamil Nadu, India.
}

Accepted 27 November, 2012

\begin{abstract}
Halotolerant $\mathrm{Cr}(\mathrm{VI})$ reducing bacteria (VITP21) was isolated from kumta coastal region, India and was identified by biochemical methods and 16S rRNA analysis as Planococcus maritimus. The halotolerant bacteria exhibited complete reduction of 100 and $200 \mathrm{mg} / \mathrm{L} \mathrm{of} \mathrm{Cr}(\mathrm{VI})$ within 24 and $28 \mathrm{~h}$, respectively and greater than $90 \%$ reduction was observed for higher concentration of $\mathrm{Cr}(\mathrm{VI})$ in the range of 300 to 500 $\mathrm{mg} / \mathrm{L}\left(\mathrm{pH} 7,35^{\circ} \mathrm{C}\right.$, and $\left.4 \% \mathrm{NaCl}\right)$. The optimum parameters for chromium reduction was found to be $\mathrm{pH}$ $7.0,35^{\circ} \mathrm{C}$ and $4 \% \mathrm{NaCl}$ with an agitation rate of $140 \mathrm{rpm}$ under aerobic condition. The isolate was capable to grow and reduce chromate even in the presence of different divalent metal ions $(50 \mathrm{mg} / \mathrm{L}$ of $\mathrm{Pb}^{2+}, \mathrm{Co}^{2+}, \mathrm{Cd}^{2+}, \mathrm{Ni}^{2+}, \mathrm{Zn}^{2+}, \mathrm{Cu}^{2+}$ and $\mathrm{Mn}^{2+}$ ) under saline conditions. Experiments with resting cells, permeabilized cells, sonicated cells and cytosolic fractions demonstrated that the chromium reduction is mainly associated with the soluble cytosolic fraction of the cell. To our knowledge, this is the first detailed report on effective reduction of $\mathrm{Cr}(\mathrm{VI})$ by halotolerant bacteria $\boldsymbol{P}$. maritimus VITP2I. The current investigation indicates that the isolated organism can promisingly contribute for the treatment of toxic hexavalent chromium present in saline industrial waste water.
\end{abstract}

Key words: Bioremediation, chromium reduction, chromium removal, halotolerant bacteria, Planococcus, saline wastewater.

\section{INTRODUCTION}

Chromium (VI), a heavy metal ion is released into the environment mainly due to chrome tanning processes, electroplating, paint and pigment manufacturing industries (Sharma et al., 2011). Among the different oxidation states, trivalent and hexavalent chromium exist as stable species. Compared to trivalent chromium, hexavalent chromium is highly toxic, mutagenic and carcinogenic (Sultan and Hasnain, 2007). The permissible limit recommended by environmental protection agency (EPA) for $\mathrm{Cr}(\mathrm{VI})$, in drinking water, is less than $50 \mu \mathrm{g} / \mathrm{L}$ (Baral and Engelken, 2002). Therefore treatment of water polluted with hexavalent chromium becomes indispensable. Conventional methods like precipitation, electrochemical treatment, ion exchange

\footnotetext{
*Corresponding author. E-mail: gjayaraman@vit.ac.in. Tel: + 91 416 2202573. Fax: + 914162243092.
}

have several disadvantages (Sannasi et al., 2006). Use of microorganisms has been shown as an alternative, as they have an ability to tolerate bio-accumulate, precipitate, adsorb or bio-convert toxic hexavalent chromium. Extensive work has been carried out on the removal of chromium by a variety of organisms (Thacker et al., 2006; Srinath et al., 2002; Jeyasingh et al., 2005; Sultan et al., 2007). However, very few microbes have been studied for their potential in removing hexavalent chromium under saline conditions. Metal removal study in the presence of salt becomes important as waste water generated by most of the industries, especially tannery waste stream contains higher concentration (1-10\% by wt) of salt as $\mathrm{NaCl}$ (Sivaprakasam et al., 2008).

Saline environment which includes sea water, salterns, soda lakes, evaporation pools inhabits several groups of organisms. The microbes which are flourishing in this habitat can withstand extreme or at least moderate saline conditions, depending on the habitat and adaptability. 
Halophilic microbes grow well in higher salt concentration whereas halotolerant microbes are capable of growing even in the absence of salt. Organisms from saline habitat have been shown to be resistant to many toxic metals as they survive in highly stress conditions (Gnanamani et al., 2010). Biological detoxification of $\mathrm{Cr}$ (VI) has been reported by a few halophilic/halotolerant organisms (Kiran et al., 2008; Amoozegar et al., 2007; Shapovalova et al., 2009; Vanengelen et al., 2008; Donmez and Kocberber, 2005). Despite the fact that these studies show promising contribution from halophilic/halotolerant species, extensive investigation on chromium reduction capability under various conditions and localization of chromium reduction is not reported for halotolerant bacteria. In order to give such insights, this report details the potential capability of a halotolerant bacterium, Planococcus maritimus VITP2I, in reducing toxic hexavalent chromium to non-toxic trivalent chromium.

\section{MATERIALS AND METHODS}

\section{Materials}

Chemicals and culture media were purchased from Himedia, Mumbai. All reagents were of analytical reagent (AR) grade. All the glasswares were washed with nitric acid solution (1:1) and rinsed thrice with distilled water before use.

\section{Halotolerant bacteria and culture condition}

Halotolerant bacterial strains were isolated from Kumta costal region of Karnataka, India and were maintained in the laboratory. Morphologically different colonies were transferred on Luria agar plate amended with 100 to $1000 \mathrm{mg} / \mathrm{L}$ of $\mathrm{Cr}(\mathrm{VI})$ as potassium dichromate and investigated for chromium resistance. Selected $\mathrm{Cr}$ (VI) resistance bacterial cultures were studied for their $\mathrm{Cr}(\mathrm{VI})$ removal potential under aerobic condition with an initial $\mathrm{Cr}$ (VI) concentration of $200 \mathrm{mg} / \mathrm{L}$. Luria Bertani medium, supplemented with $4 \%(\mathrm{w} / \mathrm{v}) \mathrm{NaCl}$ was used for all the experiments. The $\mathrm{pH}$ of the media was adjusted to 7.0 with either $1 \mathrm{M} \mathrm{NaOH}$ or $\mathrm{HCl}$. All experiments were performed in duplicates under identical conditions.

\section{Identification of isolated strain}

Morphological and physiological characteristics of isolated strain were studied as per Bergey's manual of determinative bacteriology (Holt et al., 1994). The strain was further identified by 16S rRNA amplification and nucleotide sequencing. Megablast was used to identify homologous sequences in the nucleotide database and phylogenetic tree was constructed using the neighborhood joining method.

\section{Batch removal study}

The potential halotolerant bacterial cells, maintained in agar plates, were sub cultured in $25 \mathrm{ml}$ of culture media in $100 \mathrm{ml}$ flask and used for inoculating the experimental flask. The medium $(100 \mathrm{ml})$ in $250 \mathrm{ml}$ flask containing various initial chromium concentrations ranging from 100 to $500 \mathrm{mg} / \mathrm{L}$ was inoculated with $1 \%(\mathrm{v} / \mathrm{v})$ of overnight grown cultures with optical density of 1.0 (at $600 \mathrm{~nm}$ ). Samples were collected at regular intervals and the cell growth was monitored by measuring the optical density at $600 \mathrm{~nm}$. The samples were then centrifuged at $8000 \mathrm{rpm}$ for $5 \mathrm{~min}$ and the supernatant was used for determining the concentration of chromium. Each experiment was carried out for a period until the residual concentration of hexavalent chromium was found to be same with time.

\section{Chromium removal study under varying salt $(\mathrm{NaCl})$ and chromium (VI) concentration}

The effect of salt concentration on Cr (VI) removal efficiency of the isolated strain was determined in the presence of varying concentration of $\mathrm{NaCl}(2 \%(\mathrm{w} / \mathrm{v})$ to $10 \%(\mathrm{w} / \mathrm{v}))$. Different initial chromium concentration ( $100 \mathrm{mg} / \mathrm{l}$ to $500 \mathrm{mg} / \mathrm{L}$ ) was also used in the study. Experiments were carried out in $100 \mathrm{ml}$ LB media amended with varying initial salt concentration and varying chromium concentration. The initial $\mathrm{pH}$ was maintained at 7.0. The removal efficiency was studied after $24 \mathrm{~h}$ of cell growth at $35^{\circ} \mathrm{C}$ and $140 \mathrm{rpm}$.

\section{Effect of $\mathrm{pH}$ and temperature on chromium removal}

Chromium removal by the isolated bacterial strain was investigated by varying initial $\mathrm{pH}$ and temperature. For $\mathrm{pH}$ dependence study, the strain was grown in LB media with $4 \% \mathrm{NaCl}$ at different $\mathrm{pH}(6.0$ to 10.0). The experiments were carried out at $35^{\circ} \mathrm{C}$ with an agitation rate of $140 \mathrm{rpm}$. After $24 \mathrm{~h}$ of growth, amount of hexavalent chromium in the cell free supernatant was determined. The influence of temperature on growth and chromium removal was studied by incubating the culture at different temperature $(30,35$, 40 and $45^{\circ} \mathrm{C}$ ). These experiments were performed at $\mathrm{pH} 7.0$ at constant $\mathrm{NaCl}$ concentration $(4 \% \mathrm{w} / \mathrm{v})$, initial chromium concentration $(200 \mathrm{mg} / \mathrm{L})$ and agitation rate $(140 \mathrm{rpm})$.

\section{Effect of metal ions on chromium removal}

The isolated bacterial strain was grown in the presence of cobalt chloride, nickel chloride, cadmium chloride, lead nitrate, zinc chloride, manganese chloride and copper chloride. The chromium removal was investigated in the presence of $50 \mathrm{mg} / \mathrm{L}$ of these different metal ions in the presence of $200 \mathrm{mg} / \mathrm{L}$ of chromium. Chromium removal was monitored after $24 \mathrm{~h}$ of growth at $\mathrm{pH} 7.0$, $35^{\circ} \mathrm{C}, 4 \%(\mathrm{w} / \mathrm{v})$ and an agitation rate of $140 \mathrm{rpm}$.

\section{Chromium reduction by resting cells}

Overnight grown bacterial cells (200 ml Luria broth) were harvested by centrifugation $\left(8000 \mathrm{rpm}\right.$ for $30 \mathrm{~min}$ at $\left.5^{\circ} \mathrm{C}\right)$, washed twice with $20 \mathrm{ml}$ of $10 \mathrm{mM}$ Tris $\mathrm{HCl}(\mathrm{pH} \mathrm{7.2)}$ and were resuspended in $20 \mathrm{ml}$ of the same buffer. An aliquot of the resting cells was amended with 25 and $50 \mathrm{mg} / \mathrm{L}$ of hexavalent chromium (final concentration). Heat killed cells served as control (Thacker et al., 2006). All experiments were performed at $35^{\circ} \mathrm{C}$. After incubation, the suspension was centrifuged and the cell free supernatant was investigated for chromium removal.

\section{Chromium reduction by permeabilized cells}

Overnight grown culture (200 $\mathrm{ml}$ of Luria broth) was centrifuged (8000 rpm for $30 \mathrm{~min}$ ), washed with $10 \mathrm{mM}$ Tris $\mathrm{HCl}$ buffer $(\mathrm{pH} 7.2)$ 


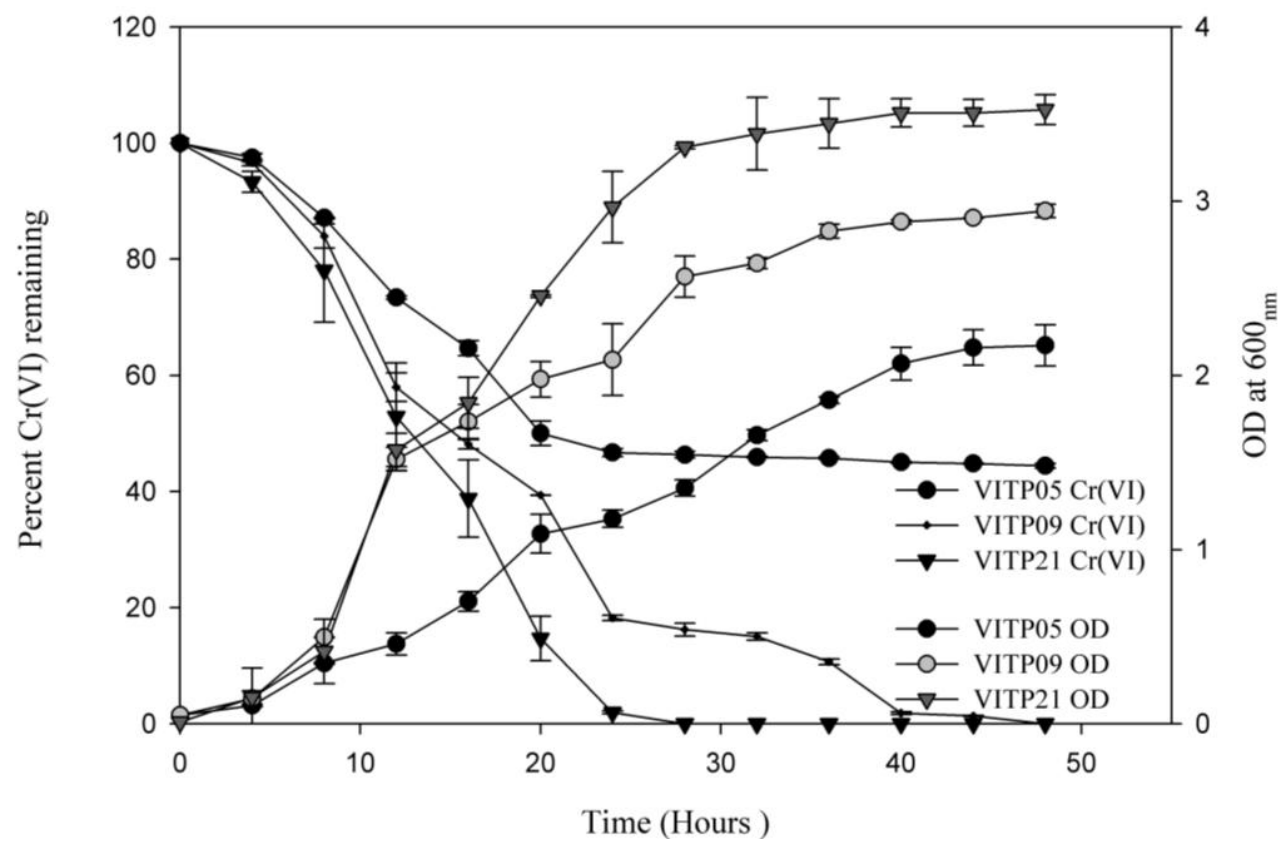

Figure 1. Microbial growth and $\mathrm{Cr}(\mathrm{VI})$ removal by different halotolerant isolates. Initial $\mathrm{Cr}(\mathrm{VI})$ concentration was $200 \mathrm{mg} / \mathrm{L}\left(4 \% \mathrm{NaCl}\right.$; $\mathrm{pH}$ 7; temperature, $35^{\circ} \mathrm{C}$; agitation rate, $\left.140 \mathrm{rpm}\right)$.

and resuspended in $20 \mathrm{ml}$ of the same buffer. Toluene $(0.01 \% \mathrm{v} / \mathrm{v})$ and Triton X $-100(0.2 \% \mathrm{v} / \mathrm{v})$ was added to the cell suspension. The prepared cell suspension was vortexed to permeabilize the cells (Thacker et al., 2006). Experiments were carried out for two different initial concentration of hexavalent chromium (25 and 50 $\mathrm{mg} / \mathrm{L})$. Heat killed permeabilized cells served as control. All the experiments were performed at $35^{\circ} \mathrm{C}$.

\section{Chromium reduction by sonicated fraction}

Experiments for chromium reduction were carried out by three different types of sonicated fractions. Bacterial cells grown overnight (200 of Luria broth) were harvested by centrifugation (8000 rpm for $30 \mathrm{~min}$ ), washed with $10 \mathrm{mM}$ Tris $\mathrm{HCl}$ buffer $(\mathrm{pH} 7.2)$ and were resuspended in $10 \mathrm{ml}$ of the same buffer. Cells were disrupted by sonication for $15 \mathrm{~min}$ (with amplitude of 40 and 60 for 10 and $5 \mathrm{~min}$, respectively) in ice cold condition with $2 \mathrm{~s}$ of pulses (Sonics INC model VC 130). The resultant suspension was centrifuged at $8000 \mathrm{rpm}$ for $60 \mathrm{~min}$ at $5^{\circ} \mathrm{C}$. Both the cytosolic and membrane suspensions were used for the experiments. In these experiments, $50 \mathrm{mg} / \mathrm{L}$ hexavalent chromium concentration was used. For all these experiment, heat killed cells were kept as control. In addition to the Diphenyl Carbazide (DPC) assay for chromium, the chromium reduction was also monitored from the change in absorbance in the wavelength range of 325 to $400 \mathrm{~nm}$, as a function of time (Shimadzu UV 2401PC).

\section{Determination of hexavalent chromium concentration and} biomass

In all experiments, concentration of hexavalent chromium was determined by diphenylcarbazide method (Thacker et al., 2006). Accordingly, the hexavalent chromium is determined spectrophotometrically by reaction with diphenylcabazide in acid solution $\left(6 \mathrm{M} \mathrm{H}_{2} \mathrm{SO}_{4}\right)$. Cell free supernatant $(200$ or $400 \mu \mathrm{l})$ was made up to $1 \mathrm{ml}$ using distilled water followed by addition of $330 \mu \mathrm{l}$ of $6 \mathrm{M} \mathrm{H}_{2} \mathrm{SO}_{4}$ and $400 \mu \mathrm{l}$ of diphenylcarbazide $(0.25 \% \mathrm{w} / \mathrm{v}$ in acetone) and final volume was made to $10 \mathrm{ml}$ using distilled water. The absorbance of the samples was read at $540 \mathrm{~nm}$ to determine the concentration of hexavalent chromium. Samples for total chromium concentration was first acid digested and were oxidized with potassium permanganate before analyzing by DPC method at $540 \mathrm{~nm}$ (Philip et al., 1998). The biomass concentration was inferred from the optical density value at $600 \mathrm{~nm}$ (Shimadzu UV 2401PC).

\section{RESULTS AND DISCUSSION}

\section{Preliminary screening for potential halotolerant isolates}

The halotolerant strains isolated from the Kumta coast were screened for their resistance against the toxic hexavalent chromium. Only three strains (VITP05, VITP09 and VITP21) were found to have significant growth in agar plates amended with higher concentration of potassium dichromate $(1000 \mathrm{mg} / \mathrm{L})$. Further confirmation of their chromium resistance was obtained by growing these bacterial strains in LB media amended with $\mathrm{Cr}(\mathrm{VI})$. All the three strains (Figure 1) showed capability of chromium removal as well as growth in the presence of initial $\mathrm{Cr}(\mathrm{VI})$ concentration of $200 \mathrm{mg} / \mathrm{L}$ at $35^{\circ} \mathrm{C}(7.0 \mathrm{pH}, 4 \% \mathrm{NaCl}$ and $140 \mathrm{rpm})$. After $24 \mathrm{~h}$ of growth, VITP21 showed $98 \%$ of chromium removal compared to VITP09 and VITP05 which showed only 82 and $53 \%$, respectively. However, after extended hours of incubation, complete chromium removal was achieved for 
strain VITP21 (28 h) and VITP09 (48 h), respectively, whereas strain VITP05 showed incomplete (44\%) chromium removal even after $48 \mathrm{~h}$ of incubation. It was also inferred, from the optical density at $600 \mathrm{~nm}$, that greater biomass was obtained with VITP21 than either VITP09 or VITP05. The chromium (VI) removal rate of VITP21, VITP09, VITP05 was found to be 7.14, 4.35 and $2.42 \mathrm{mg} / \mathrm{L}$ (per hour), respectively, thus revealing significant differences in the ability of the three halotolerant strains to remove chromium. Based on the highest removal rate and growth pattern, halotolerant bacterial strain VITP21 was used for further characterization and chromium removal studies.

\section{Characteristics of potential bacterial strain}

Morphological, physiological and biochemical characterization of the potential strain VITP21 was carried out as per the guidelines given in Bergey's manual of determinative bacteriology. The selected strain VITP21 was found to be Gram positive, circular, optically transparent filiform bacterium which formed orangeyellow colonies on the agar surface. Cells were nonsporulating, non-motile with surface texture to smooth and shiny. The strain was found to be positive only for catalase and negative to various tests like oxidase, urease, methyl red, indole production, citrate utilization, triple sugar-iron agar, mannitol motility and VogesProskauer tests. It was found that none of the carbon sources (maltose, lactose, xylose, sucrose, fructose and dextrose) were fermented by the organism. According to the Bergey's manual of determinative bacteriology, with consideration of the physiological and biochemical tests performed, the strain was tentatively named as Planococcus sp. VITP21.

The phylogenetic tree construction using the 16S rRNA sequence in MEGA 3.1 software by neighbour joining method confirmed that the organism belonged to the Planococcus cluster, with immediate neighborhoods as Planococcus maritimus strain KP8 (Gene Bank Accession number:EU594443) and Planococcaceae bacterium NR115 (Gene Bank Accession number:DQ520812). The sequence identity between the isolated organism and $P$. maritimus strain KP8 was found to be $95 \%$. Hence the isolated organism was designated as $P$. maritimus VITP2I. The ribosomal RNA gene sequence of the isolated organism has been submitted to GenBank (HQ829427).

\section{Effect of initial metal ion concentration on microbial growth and $\mathrm{Cr}(\mathrm{VI})$ removal}

Growth of the selected $P$. maritimus VITP2I strain in the presence of varying $\mathrm{Cr} \quad(\mathrm{VI})(100$ to $500 \mathrm{mg} / \mathrm{l})$ concentration was also monitored at regular intervals of time. There seems to be an increase in the lag phase with increase in $\mathrm{Cr}(\mathrm{VI})$ concentration (Figure 2A). It has to be noted that the maximum biomass obtained is almost the same in all the $\mathrm{Cr}(\mathrm{VI})$ concentrations studied and this is similar to the reports obtained by Sarangi and Krishnan (2008). At $600 \mathrm{mg} / \mathrm{L}$ of $\mathrm{Cr}(\mathrm{VI})$ concentration, bacterial growth decreased remarkably, with prolonged lag period $(40 \mathrm{~h})$, then reached to a maximum biomass concentration $\left(3.307 \mathrm{OD}_{600}\right)$ in $80 \mathrm{~h}$ of incubation (data not shown). This implies that though there was a longer lag period at higher $\mathrm{Cr}(\mathrm{VI})$ concentration, the organism could adapt suitable mechanism so as to be resistant even in the presence of higher $\mathrm{Cr}(\mathrm{VI})$ concentration. Bacillus megaterium strain TKW3 isolated from multiplemetal-contaminated marine sediments of Tokwawan, Hong Kong SAR was reported to be resistant to $0.34 \mathrm{mM}$ $\mathrm{Cr}_{2} \mathrm{O}_{7}{ }^{2-}$ (Cheng and $\mathrm{Gu}, 2005$ ). P. maritimus SS-06 was reported to be highly resistant to metals like arsenic, mercury, cobalt, cadmium, lead and selenium $\left(300 \mathrm{mmol} \mathrm{L}^{-1}\right)$ along with other bacterial isolates from Palk Bay sediment (Nithya et al., 2011). Though metal resistance/chromium resistance by moderately halophilic/halotolerant was reported for wide range of bacterial species, there is no extensive report on chromium reduction by $P$. maritimus strain.

The effect of initial $\mathrm{Cr}(\mathrm{VI})$ concentration on hexavalent chromium removal by $P$. maritimus VITP2I, was studied over a $\mathrm{Cr}(\mathrm{VI})$ concentration range of 100 to $500 \mathrm{mg} / \mathrm{L}$ in aerobic conditions $\left(\mathrm{pH} 7.0,4 \% \mathrm{NaCl}\right.$ and $\left.35^{\circ} \mathrm{C}\right)$. Substantial chromium removal occurred over the entire $\mathrm{Cr}(\mathrm{VI})$ concentration used in the study (Figure 2B). It could be seen that complete removal of chromium was achieved within 24 and $28 \mathrm{~h}$ of incubation for the initial $\mathrm{Cr}$ (VI) concentration of 100 and $200 \mathrm{mg} / \mathrm{L}$, respectively, but when the initial $\mathrm{Cr}(\mathrm{VI})$ was increased further, there was an incomplete and delayed response with respect to $\mathrm{Cr}$ (VI) removal. It was observed that 97\% (32 h), 94\% (36 h) and $91 \%(40 \mathrm{~h})$ was maximally removed for 300,400 and $500 \mathrm{mg} / \mathrm{L}$, respectively. However it should be noted that more than $90 \%$ is removed even with an initial $\mathrm{Cr}$ (VI) concentration of $500 \mathrm{mg} / \mathrm{L}$. Decrease in $\mathrm{Cr}(\mathrm{VI})$ as function of time could be either due to bioaccumulation or reduction of the metal ion. Reduction of $\mathrm{Cr}(\mathrm{VI})$ to $\mathrm{Cr}$ (III) could be confirmed by reoxidising the culture supernatant using potassium permanganate. Comparative analysis of $\mathrm{Cr}(\mathrm{VI})$ concentration, before and after oxidation is given in Table 1. It is clear that there is an increase in $\mathrm{Cr}(\mathrm{VI})$ upon oxidation, which implies that the decrease in $\mathrm{Cr}$ (VI) concentration is due to changes in the oxidation state of $\mathrm{Cr}$ (VI) to $\mathrm{Cr}$ (III). Partial removal of $\mathrm{Cr}$ (VI) (of initial concentration of $200 \mathrm{mg} / \mathrm{L}$ or more) by organisms such as Ochrobactrum intermedium SDCr-5 (Sultan and Hasnain, 2007), Providencia sp. (Thacker et al., 2006), Lysinibacillus fusiformis ZC1 (He et al., 2011) has been reported. Even bacterial sp. isolated from chromium contaminated sites had shown to exhibit less than $90 \%$ removal, even after incubation for $48 \mathrm{~h}$ or above in the 

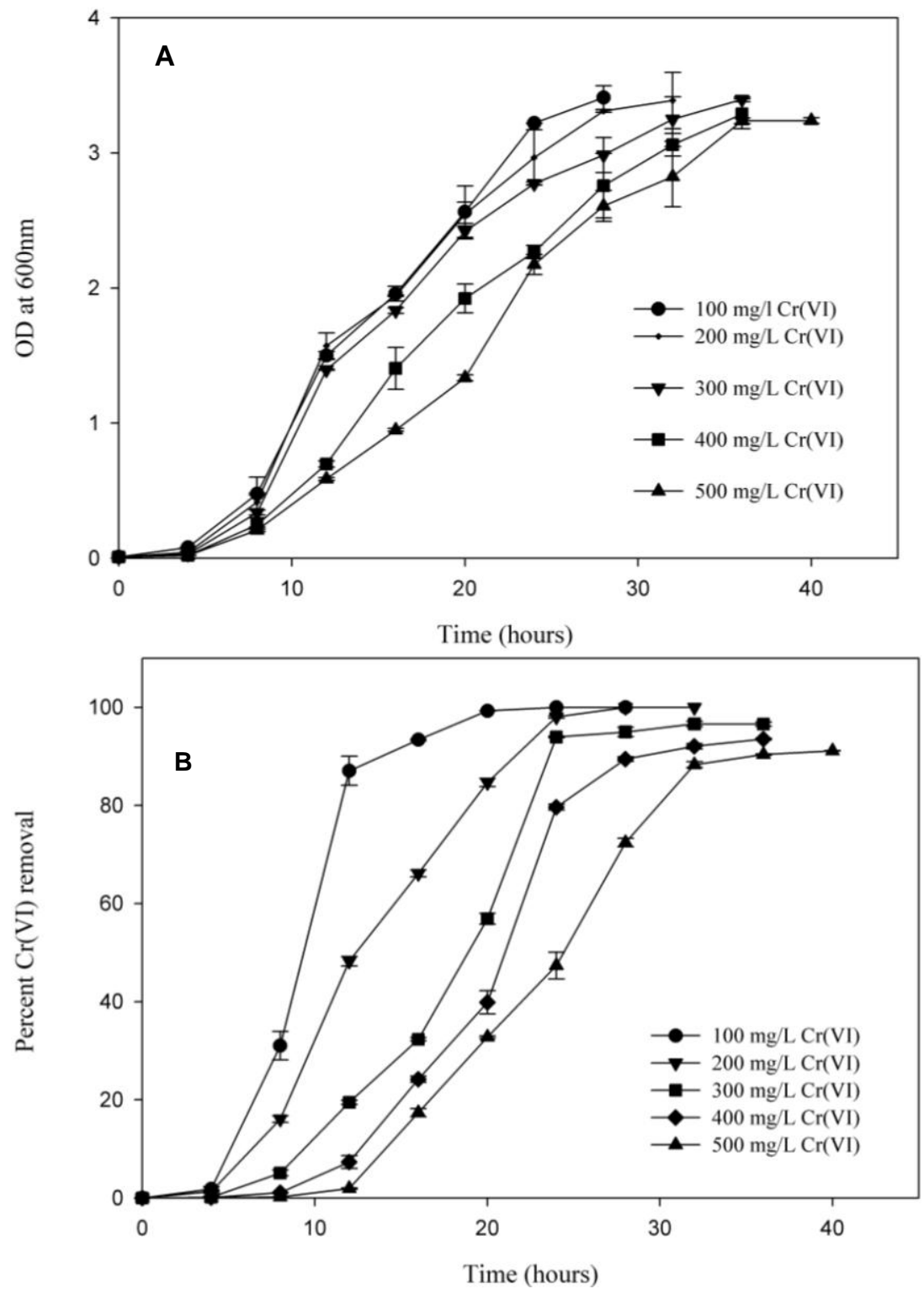

Figure 2. Effect of initial $\mathrm{Cr}(\mathrm{VI})$ concentration (100 to $500 \mathrm{mg} / \mathrm{L})$ on (A) growth of Planococcus maritimus VITP21, (B) $\mathrm{Cr}(\mathrm{VI})$ removal $(4 \% \mathrm{NaCl} ; \mathrm{pH} 7$; temperature, $35^{\circ} \mathrm{C}$; agitation rate, $\left.140 \mathrm{rpm}\right)$.

presence of lower $\mathrm{Cr}(\mathrm{VI})$ concentration (Zhang and $\mathrm{Li}$, 2011; Amoozegar et al., 2007; Zakaria et al., 2007; Desai et al., 2008b; Kathiravan et al., 2010). Complete removal/ reduction of initial chromium concentration of $200 \mathrm{mg} / \mathrm{L}$ or more, was reported using Pannonibacter phragmitetus LSSE-09 (Xu et al., 2011) and Bacillus sp., MTCC 5514 (Gnanamani et al., 2010).

\section{Effect of salt concentration on chromium removal}

As the organism is halotolerant, the ability to remove $\mathrm{Cr}$ $(\mathrm{VI})$ in the presence of increasing concentration of $\mathrm{NaCl}$
(2 to $10 \%(w / v)$ ) was studied. Figures $3 A$ and B depicts the chromium removal and biomass growth of the isolate after $24 \mathrm{~h}$ of incubation. It could be generally observed that the effect of $\mathrm{NaCl}$ is dependent on the initial $\mathrm{Cr}(\mathrm{VI})$ concentration. Present investigation reveals that for 100 and $200 \mathrm{mg} / \mathrm{L}$ of initial $\mathrm{Cr}(\mathrm{VI})$ concentration, greater than $90 \%$ of removal was observed even in the presence of 2 to $8 \% \mathrm{NaCl}$. However a substantial decrease in removal efficiency is observed in the presence of $10 \% \mathrm{NaCl}$. Such dependence of $\mathrm{Cr}(\mathrm{VI})$ removal on $\mathrm{NaCl}$ concentration was more prominent at higher initial concentration of $\mathrm{Cr}$ (VI). When the initial $\mathrm{Cr}(\mathrm{VI})$ concentration was $500 \mathrm{mg} / \mathrm{L}$, substantial removal was observed only in the presence of 
Table 1. Decrease in $\mathrm{Cr}(\mathrm{VI})$ concentration as a function of time.

\begin{tabular}{ccc}
\hline Time $(\mathbf{h})$ & $\begin{array}{c}\text { Concentration of } \mathbf{C r}(\mathbf{V I}) \text { before } \\
\text { oxidation }\end{array}$ & $\begin{array}{c}\text { Concentration of } \mathbf{C r}(\mathrm{VI}) \text { after } \\
\text { oxidation }\end{array}$ \\
\hline 0 & $200 \pm 0$ & $200 \pm 0$ \\
8 & $160.5 \pm 7.6$ & $189.9 \pm 5.2$ \\
12 & $105.7 \pm 18.8$ & $198.8 \pm 0.8$ \\
16 & $86.7 \pm 27.4$ & $191.6 \pm 8.3$ \\
20 & $31.4 \pm 9$ & $192.0 \pm 11.4$ \\
24 & $4.7 \pm 0.6$ & $197.0 \pm 4.2$ \\
28 & 0 & $197.0 \pm 4.2$ \\
\hline
\end{tabular}

Increase in $\mathrm{Cr}(\mathrm{VI})$ concentration after oxidizing the culture supernatant grown in the presence of $200 \mathrm{mg} / \mathrm{L}$ of $\mathrm{Cr}(\mathrm{VI})$ with potassium permanganate, indicate that $\mathrm{Cr}(\mathrm{VI})$ is reduced to its lower oxidation state.

$4 \% \mathrm{NaCl}(50 \%)$ and $6 \% \mathrm{NaCl}(48 \%)$ and decreased to less than $20 \%$ in the presence of $10 \% \mathrm{NaCl}$ (in $24 \mathrm{~h}$ of incubation). Chromium reduction in presence of $\mathrm{NaCl}$ by halophilic as well by non halophilic organisms has been reported (Ibrahim et al., 2011, Amoozegar et al., 2007, Cheung and Gu, 2005, Shapovalova et al., 2009 and Wani et al., 2007). Some of the reports suggest that the $\mathrm{Cr}(\mathrm{VI})$ removal efficiency of the organism decreases with increase in $\mathrm{NaCl}$ concentration (Okeke, 2008; Cetin et al., 2008). Thus the present investigation corroborate with these reports on the interdependency of $\mathrm{Cr}(\mathrm{VI})$ removal and $\mathrm{NaCl}$ concentration.

\section{Effect of temperature and $\mathrm{pH}$ on chromium removal}

In order to investigate the effect of temperature on organism's growth and chromium removal, the organism was grown at different temperatures $(30,35,40$ and $45^{\circ} \mathrm{C}$ ) in the presence of $200 \mathrm{mg} / \mathrm{L} \mathrm{Cr}(\mathrm{VI})$ (Table 2) and in the presence of $4 \% \mathrm{NaCl}$. $P$. maritimus VITP21 showed growth as well as $\mathrm{Cr}(\mathrm{VI})$ reduction in the temperature range investigated, with the maximum chromium removal of $98 \%$ and growth of $3.18 \mathrm{OD}$ at $35^{\circ} \mathrm{C}$. Beyond this temperature, there is decrease in organism growth as well as chromium removal, indicating the inter-relationship between these two parameters. Similar one-to-one correlation between growth and $\mathrm{Cr}(\mathrm{VI})$ reduction was reported by the strains Nesterenkonia sp. stain MF2 (Amoozegar et al., 2007) and Exiguobacterium sp.GS1 (Okeke, 2008).

The effect of initial $\mathrm{pH}$ on organism growth and chromium removal was investigated at an initial $\mathrm{Cr}(\mathrm{VI})$ concentration of $200 \mathrm{mg} / \mathrm{l}$ (Table 2) in the presence of $4 \%$ $\mathrm{NaCl}$. The percentage removal of chromium was greater than $80 \%$ in the $\mathrm{pH}$ range of 6.5 to 9.0 , with a maximum at $\mathrm{pH} 7.0(97 \%)$. Substantial growth and removal was not observed at $\mathrm{pH} \leq 6.0$. However, the growth and $\mathrm{Cr}(\mathrm{VI})$ removal was significant at alkaline conditions. Even at $\mathrm{pH}$
10.0 , greater than $45 \%$ of $200 \mathrm{mg} / \mathrm{L}$ of $\mathrm{Cr}(\mathrm{VI})$ was removed. Similar results indicating $\mathrm{pH}$ dependent bacterial growth and $\mathrm{Cr}$ (VI) reduction have been reported (Thacker et al., 2006; Philip et al., 1998). Recently highest reduction rate in alkaline condition (8.0 to $10.0 \mathrm{pH})$ was reported using Pannonibacter phragmitetus LSSE-09, but in the absence of $\mathrm{NaCl}$ (Xu et al., 2011).

\section{Effect of other metal ions on chromium removal}

The efficiency of $\mathrm{Cr}(\mathrm{VI})$ reduction in the presence of different heavy metal ions $(50 \mathrm{mg} / \mathrm{L})$ was also investigated, as the effluents from the industrial sites could be contaminated with various heavy metal ions. Figure 4 depicts a differential effect on $\mathrm{Cr}(\mathrm{VI})$ removal in the presence of heavy metal ions in the presence of $4 \%$ $\mathrm{NaCl}$. Greater than $85 \%$ reduction of $\mathrm{Cr}(\mathrm{VI})$ and microbial growth was observed in the presence of $\mathrm{Ni}^{2+}, \mathrm{Cu}^{2+}, \mathrm{Zn}^{2+}$ , $\mathrm{Co}^{2+}, \mathrm{Pb}^{2+}$ and $\mathrm{Mn}^{2+}$ whereas comparatively lesser chromium removal as well as microbial growth was observed in the presence of $\mathrm{Cd}^{2+}(57 \%)$. Sultan and Hasnain (2007) have reported that the efficiency of $\mathrm{Cr}$ (VI) reduction by $O$. intermedium SDCr-5 is decreased in the presence of $\mathrm{Pb}^{2+}(100 \mu \mathrm{g} / \mathrm{ml}), \mathrm{Zn}^{2+}(100 \mu \mathrm{g} / \mathrm{ml})$ and relatively lower concentration of $\mathrm{Cd}^{2+}(20 \mu \mathrm{g} / \mathrm{ml})$. Bacillus sphaericus ( $\mathrm{Pal}$ and Paul, 2004) isolated from serpentine soil have shown inhibition of chromium reduction by metal ions like $\mathrm{Ni}^{2+}, \mathrm{Co}^{2+}, \mathrm{Cd}^{2+}$ and $\mathrm{Pb}^{2+}$. These and other reports (Zakaria et al., 2007; Masood and Malik, 2011) indicated that $\mathrm{Cd}^{2+}$ interferes in $\mathrm{Cr}(\mathrm{VI})$ removal. Though in a few cases $\mathrm{Cu}^{2+}$ has been shown to have an inhibitory effect on $\mathrm{Cr}(\mathrm{VI})$, Camargo et al., (2003) have reported that $\mathrm{Cu}^{2+}$ stimulates the reduction of $\mathrm{Cr}(\mathrm{VI})$ by Bacillus sp.ES 29. Thus, the present study reveals that $P$. maritimus VITP2I can be efficiently used for $\mathrm{Cr}$ (VI) removal even in the presence of these heavy metal ions and the order of efficiency is $\mathrm{Ni}^{2+} \approx \mathrm{Cu}^{2+} \approx \mathrm{Zn}^{2+} \approx \mathrm{Co}^{2+} \approx$ 

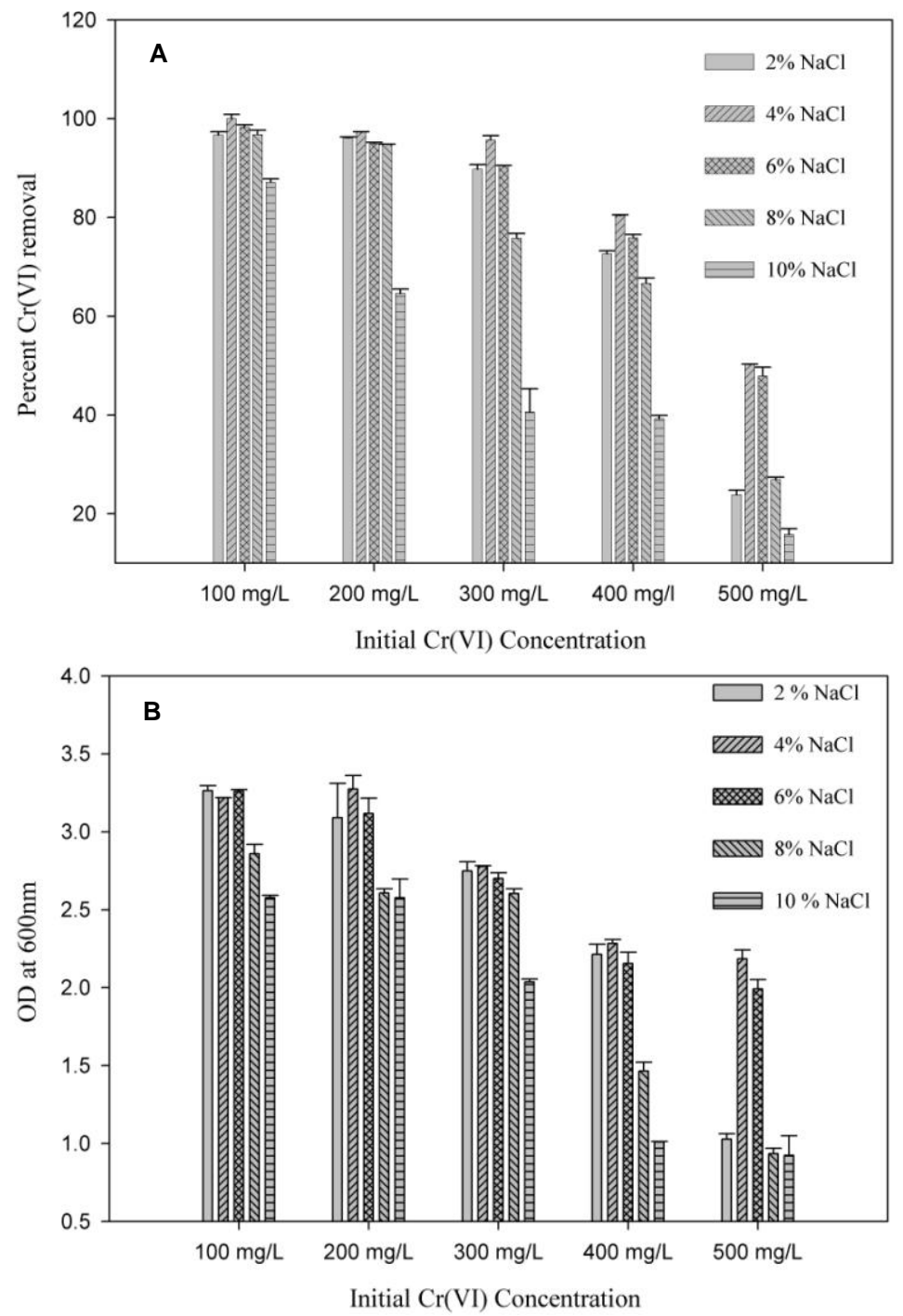

Figure 3. Effect of $\mathrm{NaCl}$ concentration (2 to $10 \% \mathrm{w} / \mathrm{v})$ ) on (A) $\mathrm{Cr}(\mathrm{VI})$ removal and (B) microbial growth in the presence of different initial $\mathrm{Cr}$ (VI) concentration(100 to $500 \mathrm{mg} / \mathrm{L}$ ) by Planococcus maritimus VITP21 $\left(\mathrm{pH} 7\right.$, temperature, $35^{\circ} \mathrm{C}$; agitation rate, $140 \mathrm{rpm}$; incubation time, $\left.24 \mathrm{~h}\right)$.

$\mathrm{Mn}^{2+}>\mathrm{Pb}^{2+}>\mathrm{Cd}^{2+}$

\section{Chromium reduction by resting cells and permeabilized cells}

In order to get further insight into the mechanism of $\mathrm{Cr}$ (VI) reduction, both resting cells and permeabilized cells were used for the study for two different initial $\mathrm{Cr}$ (VI) concentrations (25 and $50 \mathrm{mg} / \mathrm{l})$. Table 3 indicates that the resting cells was able to reduce only $58 \%$ of $\mathrm{Cr}(\mathrm{VI})$ in $30 \mathrm{~min}$ and increased to $90 \%$ after incubation for $2 \mathrm{~h}$. However, when the cells were treated with either TritonX100 or toluene the percentage of $\mathrm{Cr}(\mathrm{VI})$ reduction increased significantly, indicating that $100 \% \mathrm{Cr}$ (VI) reduction could be achieved in the presence of these permeabilizing agents. Permeabilization induced enhancement in $\mathrm{Cr}(\mathrm{VI})$ reduction has been reported using Ochrabactrum intermedium SDCr-5 sp. (Sultan and Hasnain, 2007) and Providencia sp. (Thacker et al., 2006).

\section{Chromium reduction by sonicated fractions}

Different cell fractions were investigated to ensure the localization of chromium reduction in the isolated halotolerant bacteria. The cells were sonicated (after removing the extracellular medium) and centrifuged. It has to be pointed out that the extracellular medium did 
Table 2. Effect of temperature and initial $\mathrm{pH}$ on $\mathrm{Cr}(\mathrm{VI})$ removal and growth.

\begin{tabular}{ccc}
\hline Parameter & Percent $\mathrm{Cr}(\mathrm{VI})$ removal & OD at $600 \mathrm{~nm}$ \\
\hline Temperature & & \\
$30^{\circ} \mathrm{C}$ & $82.1 \pm 4.7$ & $2.1 \pm 0.01$ \\
$35^{\circ} \mathrm{C}$ & $98.2 \pm 0.38$ & $3.2 \pm 0.04$ \\
$40^{\circ} \mathrm{C}$ & $57.6 \pm 1.5$ & $1.4 \pm 0.14$ \\
$45^{\circ} \mathrm{C}$ & $15.9 \pm 1.06$ & $0.6 \pm 0.001$ \\
& & \\
$\mathbf{p H}$ & & \\
6 & $4.3 \pm 0.8$ & $0.2 \pm 0.0$ \\
6.5 & $96.5 \pm 0.7$ & $3.1 \pm 0.01$ \\
7 & $98.01 \pm 0.6$ & $3.2 \pm 0.06$ \\
8 & $86.7 \pm 0.9$ & $3.1 \pm 0.09$ \\
9 & $81.9 \pm 1.4$ & $2.7 \pm 0.24$ \\
10 & $45.5 \pm 4.1$ & $1.1 \pm 0.16$ \\
\hline
\end{tabular}

The experiments were performed with an initial $\mathrm{Cr}(\mathrm{VI})$ concentration of $200 \mathrm{mg} / \mathrm{Land}$ in the presence of $4 \% \mathrm{NaCl}$.

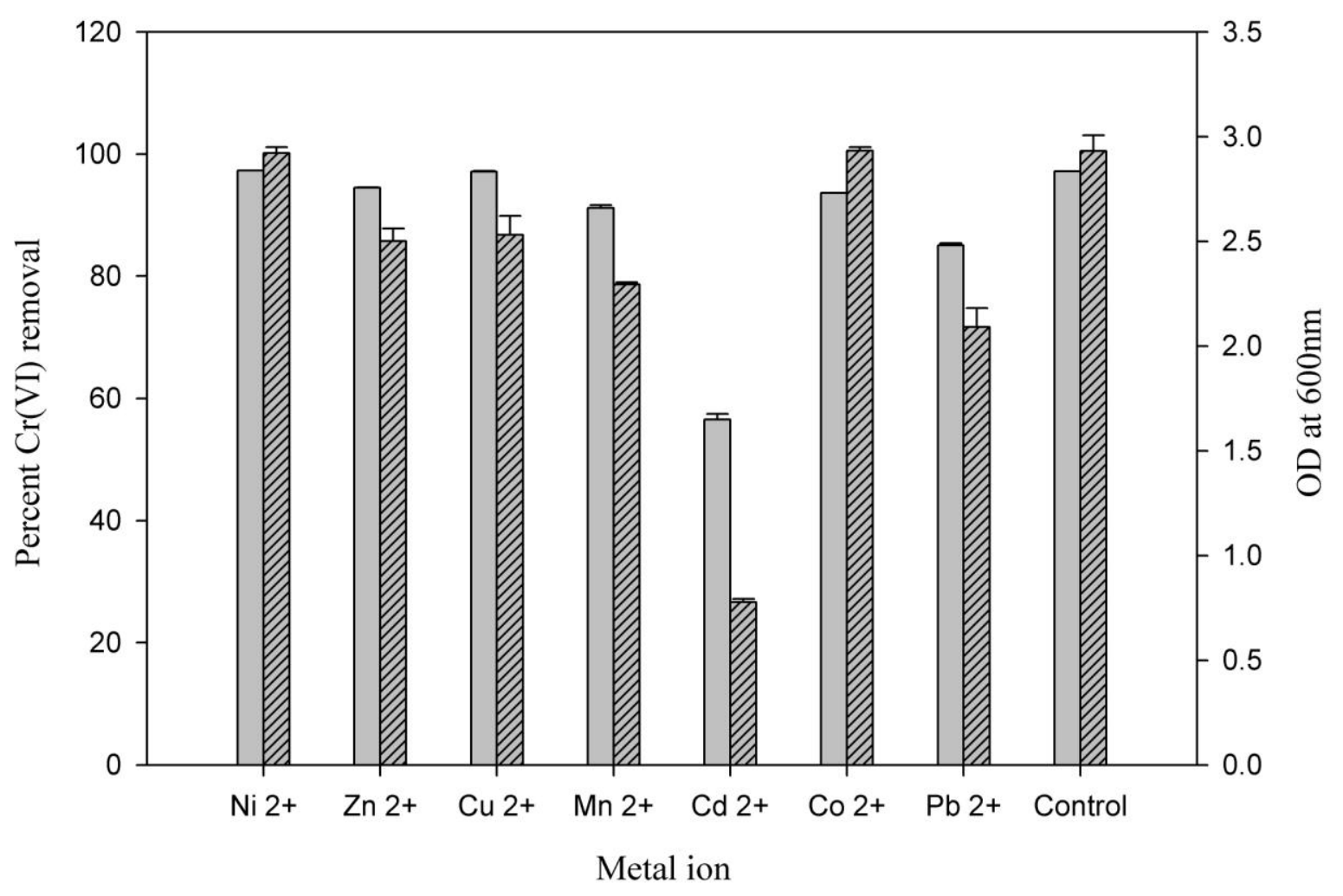

Figure 4. Effect of different metal ions $(50 \mathrm{mg} / \mathrm{L})$ on $\mathrm{Cr}(\mathrm{VI})$ removal by Planococcus maritimus VITP21. Initial $\mathrm{Cr}$ ( $\mathrm{VI}$ ) concentration was $200 \mathrm{mg} / \mathrm{L}\left(4 \% \mathrm{NaCl}, \mathrm{pH} 7\right.$; temperature, $35^{\circ} \mathrm{C}$; agitation rate, $140 \mathrm{rpm}$; incubation time, $\left.24 \mathrm{~h}\right)$.

not contribute to $\mathrm{Cr}(\mathrm{VI})$ reduction (data not shown). The sonicated fractions were then incubated with $50 \mathrm{mg} / \mathrm{L} \mathrm{Cr}$ (VI). Table 4 indicates that among the different fractions used, the cytosolic fraction was capable of reducing $\mathrm{Cr}$
$(\mathrm{VI})$ to the extent of $85 \%$ in $30 \mathrm{~min}$ and $97 \%$ in $2 \mathrm{~h}$. However, no significant reduction of $\mathrm{Cr}(\mathrm{VI})$ was observed with the membrane suspension. To confirm this, the cytosolic fraction was mixed with the membrane 
Table 3. Percent $\mathrm{Cr}(\mathrm{VI})$ reduced by resting and permeabilized cells.

\begin{tabular}{lcc}
\hline Cell type (mg/l) & $\mathbf{3 0 ~} \mathbf{~ i n}$ & $\mathbf{2} \mathbf{~}$ \\
\hline Resting cells & & \\
25 & 58.2 & 90.6 \\
50 & 25.6 & 80.8 \\
& & \\
Permeabilized cells (Triton X100 treated) & & \\
25 & 68.4 & 100 \\
50 & 40.5 & 91.6 \\
& & \\
Permeabilized cells (Toluene treated) & & \\
25 & 64.4 & 100 \\
50 & 34.5 & $94 . .0$ \\
\hline
\end{tabular}

Table 4. Percent $\mathrm{Cr}(\mathrm{VI})$ reduced by sonicated fractions $(\mathrm{Cr}(\mathrm{VI}) 50 \mathrm{mg} / \mathrm{L})$

\begin{tabular}{lcc}
\hline Sonicated fraction & $\mathbf{3 0 ~} \mathbf{~ i n}$ & $\mathbf{2 ~ h}$ \\
\hline Soluble cytosolic fractions & 85.3 & 97.2 \\
Soluble cytosolic fractions and insoluble membrane fractions & 91.6 & 97.5 \\
Insoluble membrane fractions & 1.5 & 36.6 \\
\hline
\end{tabular}

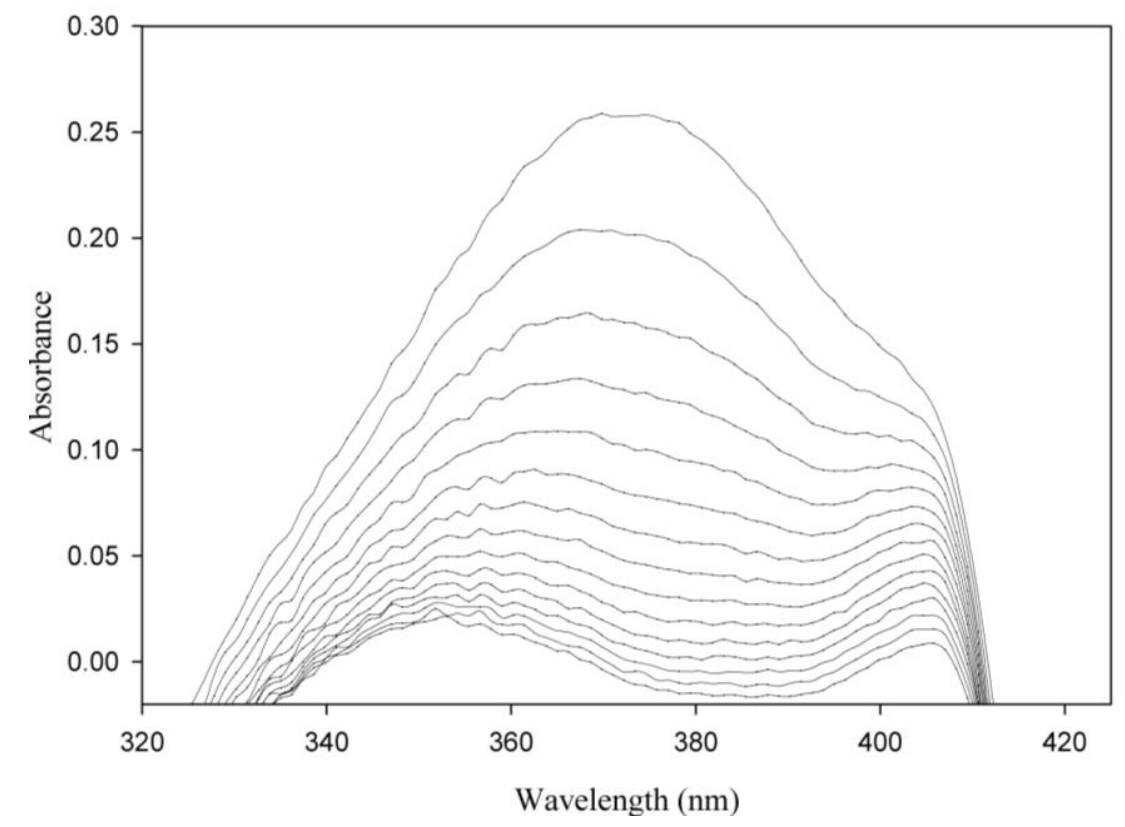

Figure 5. UV spectrum of the cytosolic fraction as a function of time. The decrease in absorbance and shift in $\lambda_{\max }$ is indicative of change in oxidation state of $\mathrm{Cr}(\mathrm{VI})$.

suspension. This formulation revealed $97 \%$ reduction in 2 $\mathrm{h}$, which is equivalent to the contribution of the cytosolic fraction indicating that only the cytosolic fraction contributes to $\mathrm{Cr}(\mathrm{VI})$ reduction. Further confirmation in this regard, was achieved by monitoring the changes in the absorbance of the $\mathrm{Cr}$ (VI) reduction spectrophotometrically. Figure 5 indicates that the absorbance of the $\mathrm{Cr}(\mathrm{VI})$ treated with the cytosolic fraction decreases as a function of time, further confirming that the reduction of $\mathrm{Cr}(\mathrm{VI})$ is effected by the 
cytosolic fraction. Such reports on the localization of $\mathrm{Cr}$ (VI) reductase activity in the soluble component of the cell had been demonstrated in Brucella sp. (Thacker et al., 2007), B. sphaericus AND 303 (Pal et al., 2005), Bacillus sp. (Desai et al., 2008a), Providencia sp. (Thacker et al., 2006), Arthrobacter sp. and Bacillus sp. (Megharaj et al., 2003). Membrane associated Cr (VI) reduction was also reported in Pseudomonas fluorescens strain LB300 (Bopp and Ehrlich, 1988), Enterobacter cloacae HO1 (Wang et al., 1990) Thermus scotoductus SA-01 (Opperman et al., 2008). However in the present study, cytosolic fractions of halotolerant bacteria, $P$. maritimus VITP2I grown in LB medium (amended with $4 \% \mathrm{NaCl}$ ) and in the absence of hexavalent chromium reduced $\mathrm{Cr}(\mathrm{VI})$, was capable of reducing $\mathrm{Cr}(\mathrm{VI})$. This vividly indicates the enzymes involved in $\mathrm{Cr}(\mathrm{VI})$ is not induced by the presence of $\mathrm{Cr}(\mathrm{VI})$ but is naturally expressed in the system.

In conclusion, the bacterial isolate P. maritimus VITP2I, reported in this study shows remarkable capacity to reduce $\mathrm{Cr}(\mathrm{VI})$ under saline environment over a broad $\mathrm{pH}$ range and in the presence of different heavy metal ions. The reduction is effected by the cytosolic components. The study also reveals that the isolated strain is capable of tolerating higher concentration of $\mathrm{Cr}(\mathrm{VI})$. Thus the results of this study provide the first detailed report of the potential application of $P$. maritimus VITP2I in chromium bioremediation, even under saline conditions and in the presence of other heavy metal ions.

\section{ACKNOWLEDGEMENTS}

The authors thank VIT University for providing the necessary support.

\section{REFERENCES}

Amoozegar MA, Ghasemi A, Razavi MR, Naddaf S (2007). Evaluation of hexavalent chromium reduction by chromate-resistant moderately halophile, Nesterenkonia sp. strain MF2. Process Biochem. 42:14751479

Baral A, Engelken RD (2002). Chromium-based regulations and greening in metal finishing industries in the USA. Environ. Sci. Policy 5:121-133

Bopp LH, Ehrlich HL (1988). Chromate resistance and reduction in Pseudomonas fluorescence strain LB300. Arch. Microbiol. 150:42631.

Camargo FAO, Okeke BC, Bento FM, Frankenberger WT (2003). In vitro reduction of hexavalent chromium by a cell-free extract of Bacillus sp. ES 29 stimulated by $\mathrm{Cu}^{2+}$. Appl. Microbiol. Biotechnol. 62:569-573.

Cetin D, Donmez S, Donmez G (2008). The treatment of textile wastewater including chromium (VI) and reactive dye by sulfatereducing bacterial enrichment. J. Environ. Manag. 88:76-82.

Cheung KH, Gu JD (2005). Chromate reduction by Bacillus megaterium TKW3 isolated from marine sediments. World J. Microbiol. Biotechnol. 21:213-219.

Desai C, Jain K, Madamwar D (2008a). Evaluation of in vitro $\mathrm{Cr}(\mathrm{VI})$ reduction potential in cytosolic extracts of three indigenous Bacillus $\mathrm{sp}$. isolated from $\mathrm{Cr}(\mathrm{VI})$ polluted industrial landfill. Bioresour. Technol. 99:6059-6069.
Desai C, Jain K, Madamwar D (2008b). Hexavalent chromate reductase activity in cytosolic fractions of Pseudomonas sp. G1DM21 isolated from $\mathrm{Cr}(\mathrm{VI})$ contaminated industrial landfill. Process Biochem. 43:713-721.

Donmez G, Kocberber N (2005). Isolation of hexavalent chromium resistant bacteria from industrial saline effluents and their ability of bioaccumulation. Enzy. Microb. Technol. 36:700-705.

Gnanamani A, Kavitha V, Radhakrishanan N, Rajkumar S, Sekaran G, Mandal AB (2010). Microbial products (biosurfactant and extracellular chromate reductase) of marine microorganism are the potential agents reduce the oxidative stress induced by toxic heavy metals. Colloid Surf. B. 79:334-339.

He M, Li X, Liu H, Miller SJ, Wang G, Rensing C (2011). Characterization and genomic analysis of a highly chromate resistan and reducing bacterial strain Lysinibacillus fusiformis ZC1. J. Hazard. Mater. 185:682-688

Holt JG, Krieg RN, Sneath PHA, Staley JT, Williams ST (1994). Bergey's manual of determinative bacteriology. USA: Williams and Wilkins.

Ibrahim ASS, El-Tayeb MA, Elbadawi YB, AI-Salama AA (2011). Bioreduction of $\mathrm{Cr}(\mathrm{VI})$ by potent novel chromate resistant alkaliphilic Bacillus sp. strain KSUCr5 isolated from hypersaline Soda lakes. Afr. J. Biotechnol. 37:7207-7218.

Jeyasingh J, Philip L (2005). Bioremediation of chromium contaminated soil: optimization of operating parameters under laboratory conditions. J. Hazard. Mater. 118:113-120.

Kathiravan MN, Karthick R, Muthu N, Muthukumar K, Velan M (2010). Sonoassisted microbial reduction of chromium. Appl. Biochem. Biotechnol. 160:2000-2013.

Kiran, Bala, Nisha R, Anubha K (2008). Chromium (VI) tolerance in two halotolerant strains of Nostoc. J. Environ. Biol. 29:155-158.

Masood F, Malik A (2011). Hexavalent chromium reduction by Bacillus sp. strain FM1 isolated from heavy-metal contaminated soil. Bull. Environ. Contam. Toxicol. 86:114-119.

Megharaj M, Avudainayagam S, Naidu R (2003). Toxicity of hexavalent chromium and its reduction by bacteria isolated from soil contaminated with tannery waste. Curr. Microb. 47:51-54.

Nithya C, Gnanalakshmi B, Pandian SK (2011). Assessment and characterization of heavy metal resistance in Palk Bay sediment bacteria. Mar. Environ. Res. 71:283-294.

Okeke BC (2008). Bioremoval of hexavalent chromium from water by a salt tolerant bacterium, Exiguobacterium sp. GS1. J. Ind. Microbiol. Biotechnol. 35:1571-1579.

Opperman DJ, Van Heerden E (2008). A membrane-associated protein with $\mathrm{Cr}(\mathrm{VI})$-reducing activity from Thermus scotoductus SA-01. FEMS Microbiol. Lett. 280:210-218.

Pal A, Dutta S, Paul AK (2005). Reduction of hexavalent chromium by cell-free extract of Bacillus sphaericus and 303 isolated from serpentine soil. Curr. Microbiol. 51:327-330.

Pal A, Paul AK (2004). Aerobic chromate reduction by chromiumresistant bacteria isolated from serpentine soil, Microbiol. Res. 159:347-354

Philip L, lyengar L, Venkobachar C (1998). Cr(VI) reduction by Bacillus coagulans isolated from contaminated soils. J. Environ. Eng. 124:1165-1170.

Sannasi P, Kader J, Ismail BS, Salmijah S (2006). Sorption of $\mathrm{Cr}(\mathrm{VI})$, $\mathrm{Cu}(\mathrm{II})$ and $\mathrm{Pb}(\mathrm{II})$ by growing and non-growing cells of a bacterial consortium. Bioresour. Technol. 97:740-747.

Sarangi A, Krishnan C (2008). Comparison of in vitro $\mathrm{Cr}$ (VI) reduction by CFEs of chromate resistant bacteria isolated from chromate contaminated soil. Bioresour. Technol. 99:4130-4137.

Shapovalova AA, Khijniak TV, Tourova TP, Sorokin DY (2009). Halomonas chromatireducens sp. nov., a new denitrifying facultatively haloalkaliphilic bacterium from solonchak soil capable of aerobic chromate reduction. Microbiology 78:102-111.

Sharma S, Adholeya A (2011). Detoxification and accumulation of chromium from tannery effluent and spent chrome effluent by Paecilomyces lilacinus fungi. Int. Biodeterior. Biodegradation 65:309317.

Sivaprakasam S, Mahadevan S, Sekar S, Rajakumar S (2008). Biological treatment of tannery wastewater by using salt-tolerant bacterial strains. Microb. Cell Fact. 7:15. 
Srinath T, Verma T, Ramteke PW, Garg SK (2002). Chromium (VI) biosorption and bioaccumulation by chromate resistant bacteria. Chemosphere 48:427-435.

Sultan S, Hasnain S (2007). Reduction of toxic hexavalent chromium by Ochrobactrum intermedium strain SDCr-5 stimulated by heavy metals. Bioresour. Technol. 98:340-344.

Thacker U, Parikh R, Shouche Y, Madamwar D (2006). Hexavalent chromium reduction by Providencia sp. Process Biochem. 41:13321337.

Thacker U, Parikh R, Shouche Y, Madamwar D (2007). Reduction of chromate by cell-free extract of Brucella sp. isolated from $\mathrm{Cr}(\mathrm{VI})$ contaminated sites. Bioresour. Technol. 98:1541-1547.

Vanengelen MR, Peyton BM, Mormile MR, Pinkart HC (2008). Fe (III), $\mathrm{Cr}(\mathrm{VI})$, and $\mathrm{Fe}(\mathrm{III})$-mediated $\mathrm{Cr}(\mathrm{VI})$ reduction in alkaline media using a Halomonas isolate from Soap Lake, Washington. Biodegradation 19:841-850.

Wang PC, Mori T, Toda K, Ohtake H (1990). Membrane-associated chromate reductase activity from Enterobacter cloacae. J. Bacteriol. 172:1670-1672.
Wani R, Kodam KM, Gawai KR, Dhakephalkar PK (2007). Chromate reduction by Burkholderia cepacia MCMB-821, isolated from the pristine habitat of alkaline crater lake. Appl. Microbiol. Biotechnol. 75:627-632.

Xu L, Luo M, Li W, Wei X, Xie K, Liu L, Jiang C, Liu H (2011). Reduction of hexavalent chromium by Pannonibacter phragmitetus LSSE-09 stimulated with external electron donors under alkaline conditions. J. Hazard. Mater. 185:1169-1176.

Zakaria ZA, Zakaria Z, Surif S, Ahmada WA (2007). Hexavalent chromium reduction by Acinetobacter haemolyticus isolated from heavy-metal contaminated wastewater. J. Hazard. Mater. 146:30-38.

Zhang K, Li F (2011). Isolation and characterization of a chromiumresistant bacterium Serratia sp. Cr-10 from a chromate-contaminated site. Appl. Microbiol. Biotechnol. 90:1163-1169. 